\title{
Rosiglitazone Attenuated Endothelin-1-Induced Vasoconstriction of Pulmonary Arteries in the Rat Model of Pulmonary Arterial Hypertension via Differential Regulation of ET-1 Receptors
}

\author{
Yahan Liu, ${ }^{1}$ Xiao Yu Tian, ${ }^{2}$ Yu Huang, ${ }^{2}$ and Nanping Wang ${ }^{1,3}$ \\ ${ }^{1}$ Institute of Cardiovascular Science, Peking University Health Science Center, Beijing 100191, China \\ ${ }^{2}$ Institute of Vascular Medicine, Li Ka Shing Institute of Health Sciences, School of Biomedical Sciences, \\ Chinese University of Hong Kong, Hong Kong \\ ${ }^{3}$ Cardiovascular Research Center, Xi'an Jiaotong University, Xian, Shaanxi 710061, China
}

Correspondence should be addressed to Nanping Wang; nanpingwang2003@yahoo.com

Received 25 October 2013; Accepted 3 January 2014; Published 18 February 2014

Academic Editor: Tianxin Yang

Copyright (c) 2014 Yahan Liu et al. This is an open access article distributed under the Creative Commons Attribution License, which permits unrestricted use, distribution, and reproduction in any medium, provided the original work is properly cited.

\begin{abstract}
Pulmonary arterial hypertension (PAH) is a fatal disease characterized by a progressive increase in pulmonary arterial pressure leading to right ventricular failure and death. Activation of the endothelin (ET)-1 system has been demonstrated in plasma and lung tissue of PAH patients as well as in animal models of PAH. Recently, peroxisome proliferator-activated receptor $\gamma$ (PPAR $\gamma$ ) agonists have been shown to ameliorate PAH. The present study aimed to investigate the mechanism for the antivasoconstrictive effects of rosiglitazone in response to ET-1 in PAH. Sprague-Dawley rats were exposed to chronic hypoxia (10\% oxygen) for 3 weeks. Pulmonary arteries from PAH rats showed an enhanced vasoconstriction in response to ET-1. Treatment with PPAR $\gamma$ agonist rosiglitazone ( $20 \mathrm{mg} / \mathrm{kg}$ per day) with oral gavage for 3 days attenuated the vasocontractive effect of ET-1. The effect of rosiglitazone was lost in the presence of $\mathrm{L}_{\mathrm{L}}$-NAME, indicating a nitric oxide-dependent mechanism. Western blotting revealed that rosiglitazone increased $\mathrm{ET}_{\mathrm{B}} \mathrm{R}$ but decreased $\mathrm{ET}_{\mathrm{A}} \mathrm{R}$ level in pulmonary arteries from PAH rats. $\mathrm{ET}_{\mathrm{B}} \mathrm{R}$ antagonist $\mathrm{A} 192621$ diminished the effect of rosiglitazone on ET-1-induced contraction. These results demonstrated that rosiglitazone attenuated ET-1-induced pulmonary vasoconstriction in PAH through differential regulation of the subtypes of ET-1 receptors and, thus, provided a new mechanism for the therapeutic use of PPAR $\gamma$ agonists in PAH.
\end{abstract}

\section{Introduction}

Pulmonary arterial hypertension (PAH) is characterized by a progressive increase of pulmonary vascular resistance, leading to right ventricular failure and death [1]. ET-1 plasma level was elevated in the patients and experimental models for PAH $[2,3]$. Expression of ET-1 was increased in lung tissues of PAH patients, predominantly in pulmonary arteries $[4,5]$. ET- 1 has 2 major subtypes of receptors: $E T-A$ receptor $\left(E_{A} R\right)$ is expressed on vascular smooth muscle cells (SMCs) and mediates vasoconstriction, whereas ET-B receptor $\left(\mathrm{ET}_{\mathrm{B}} \mathrm{R}\right)$ is predominantly expressed in endothelial cells (ECs), where it primarily mediates vasodilatation and the clearance of ET1. Expression of $\mathrm{ET}_{\mathrm{A}} \mathrm{R}$ was upregulated in the lung tissues and pulmonary arteries from $\mathrm{PAH}$ patients with a wellestablished pathophysiological role [6-8]. However, a role of $\mathrm{ET}_{\mathrm{B}} \mathrm{R}$ was rather controversial with the reports of unaltered, increased, or decreased expressions in the vessel tissues from various PAH conditions [9-15].

Emerging evidence suggests that peroxisome proliferatoractivated receptor- $\gamma$ (PPAR $\gamma)$ agonists might have therapeutic role in treating PAH [16]. PPAR $\gamma$ regulates the transcription of genes involved in glucose and lipid metabolism, inflammation, as well as vascular remodeling [17-19]. The 


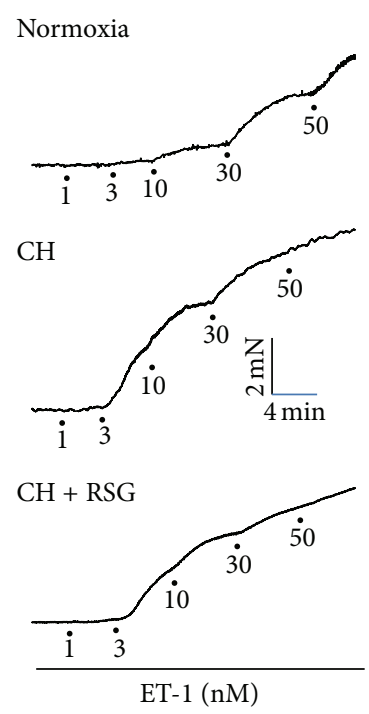

(a)

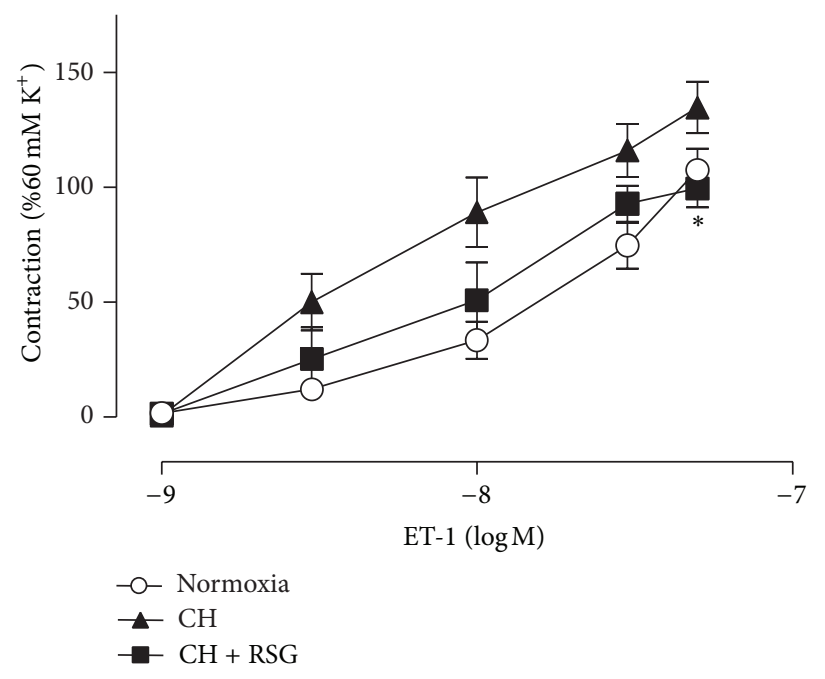

(b)

FIGURE 1: (a) Representative recordings of ET-1-induced contractions of pulmonary arteries from normoxia-, chronically hypoxic- (CH-), or rosiglitazone- (RSG-) treated CH-rats. (b) RSG ameliorated ET-1-mediated vasoconstriction in pulmonary arteries from the rats with PAH. Data were mean \pm SEM from 5 to 7 rats. ${ }^{*} P<0.05 \mathrm{CH}+\mathrm{RSG}$ versus $\mathrm{CH}$ group.

expression of PPAR $\gamma$ was reduced in the lungs from the PAH patients and the rat models $[20,21]$. Similarly, mice with deletion of PPAR $\gamma$ in SMCs or ECs developed PAH. Pharmacological activation of PPAR $\gamma$ ameliorated PAH. [21-25]. In ECs, $\operatorname{PPAR} \gamma$ activators inhibited thrombin- or oxidized low-density lipoproteins- (LDL-) induced ET-1 production $[26,27]$. In particular, we recently observed that PPAR $\gamma$ agonist rosiglitazone attenuated ET-1-induced vasoconstriction through upregulation of $\mathrm{ET}_{\mathrm{B}} \mathrm{R}$ in ECs [28]. However, whether the regulation of $\mathrm{ET}_{\mathrm{B}} \mathrm{R}$ accounts for the ameliorative effect of PPAR $\gamma$ agonists in PAH arteries remains to be elucidated. In the present study, we examined the role of rosiglitazone on ET-1-induced vasocontraction of pulmonary arteries in rat $\mathrm{PAH}$ models and the underlying mechanism.

\section{Materials and Methods}

2.1. Animals, Cell Culture, and Reagents. Male SpragueDawley rats were used and the experiments were conducted in accordance with the National Institutes of Health (NIH) Guide for the Care and Use of Laboratory Animals with the approval by the institutional committee. Polyclonal rabbit anti-ET $\mathrm{B}_{\mathrm{B}} \mathrm{R}$ antibody was from Abcam. Polyclonal rabbit anti$\mathrm{ET}_{\mathrm{A}} \mathrm{R}$ was from Santa Cruz Biotechnology. ET-1 and $N^{\mathrm{G}}$ nitro- ${ }_{L}$-arginine methyl ester $\left({ }_{L}-\mathrm{NAME}\right)$ were from SigmaAldrich Co., rosiglitazone was from GlaxoSmithKline, and A192621 was from Abbott Laboratories.

2.2. Chronic Hypoxia Induced PAH in Rat. Rats were exposed to normobaric hypoxia ( $10 \%$ oxygen) or normoxia $(21 \%$ oxygen) for 3 weeks and then treated with rosiglitazone (20 mg/kg per day) or water with oral gavage for 3 days.
2.3. Isometric Tension Measurement. Left lungs were removed and placed in oxygenated Krebs-Henseleit solution. Pulmonary arteries were carefully dissected from adjacent connective tissue and cut into several ring segments of $\approx 2 \mathrm{~mm}$ long for measuring isometric force. Organ chambers (Multi Myograph System, Danish Myo Technology A/S) were filled with $\left(37^{\circ} \mathrm{C}\right)$ Krebs solution containing (in mmol/L) 119.0 $\mathrm{NaCl}, 4.7 \mathrm{KCl}, 2.5 \mathrm{CaCl}_{2}, 1.0 \mathrm{MgCl}_{2}, 25.0 \mathrm{NaHCO}_{3}, 1.2$ $\mathrm{KH}_{2} \mathrm{PO}_{4}$, and $11.0_{\mathrm{D}}$-glucose. The Krebs solution in the organ bath was initially open to room air, being bubbled with mixed $95 \% \mathrm{O}_{2}$ and $5 \% \mathrm{CO}_{2}$. Each ring was suspended between 2 tungsten wires (diameter, $40 \mu \mathrm{m}$ ) in the chamber under optimal resting tension $(2.5 \mathrm{mN}$ as previously determined for the pulmonary arteries) and left for 90-minute equilibration. Vasoreactivity was measured to compare contractions in response to ET-1 (1 to $50 \mathrm{nmol} / \mathrm{L})$ in the absence and presence of ${ }_{\mathrm{L}}$-NAME $(100 \mu \mathrm{mol} / \mathrm{L})$. The effects of antagonist of $\mathrm{ET}_{\mathrm{B}} \mathrm{R}$ were tested on ET-1-induced contractions.

2.4. Western Blot Analysis. Pulmonary arteries were dissected, frozen in liquid nitrogen, and homogenized in RIPA lysis buffer containing protease inhibitors. Protein lysates separated on $12.5 \%$ sodium dodecyl sulfate polyacrylamide gels (SDS-PAGE) and transferred to PVDF membranes, which were blocked with $5 \%$ nonfat milk in Tris-buffered saline-Tween $(0.2 \%)$ (TBS-T) for $1 \mathrm{~h}$, incubated overnight with primary antibody and then horseradish peroxidase(HRP-) conjugated secondary antibody, and visualized with ECL reagent.

2.5. Statistical Analysis. Results represent mean \pm SEM. Comparisons among groups involved ANOVA followed by 


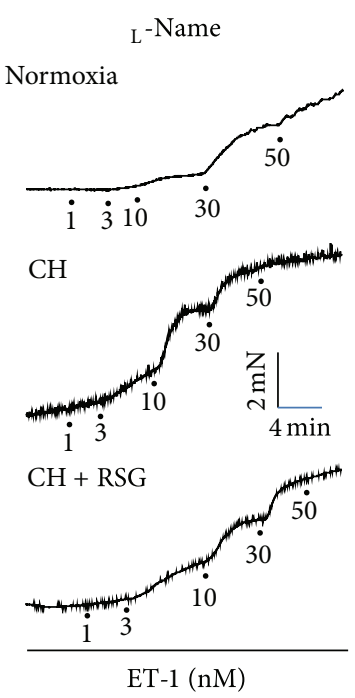

(a)

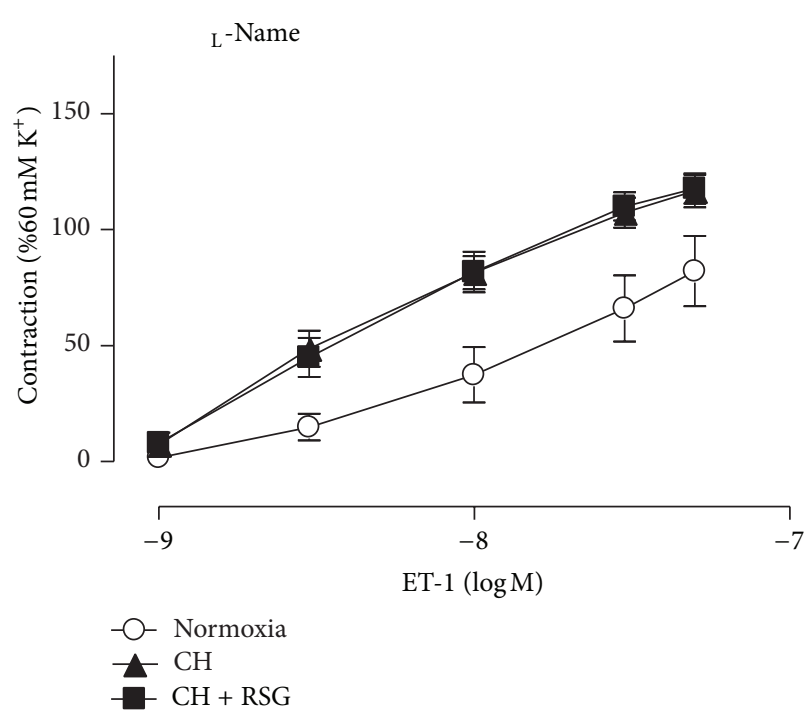

(b)

Figure 2: (a) Representative recordings of ET-1-induced contractions pretreated with ${ }_{\mathrm{L}}$-NAME $(100 \mu \mathrm{mol} / \mathrm{L})$ in pulmonary arteries from normoxia-, CH-, or RSG-treated CH-rats. (b) The effect of RSG on ET-1-mediated vasoconstriction was abrogated in the presence of L $_{\text {-NAME }}$ $(100 \mu \mathrm{mol} / \mathrm{L})$. Data were mean \pm SEM from 5 to 7 rats.

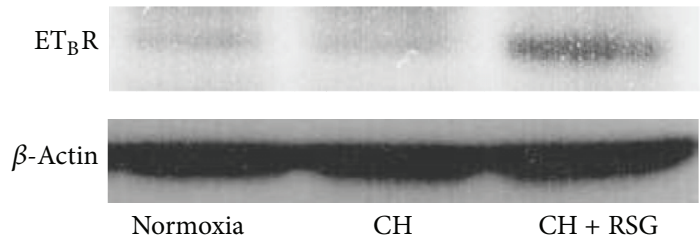

FIGURE 3: Rosiglitazone upregulated $\mathrm{ET}_{\mathrm{B}} \mathrm{R}$ expression in rats with $\mathrm{PAH}$. Western blotting was performed with the protein samples extracted from the pulmonary arteries of normoxia-, $\mathrm{CH}-$, or RSGtreated $\mathrm{CH}$-rats. Data shown are representative of three independent experiments.

unpaired Student's $t$-test. $P<0.05$ was considered statistically significant.

\section{Results}

3.1. Rosiglitazone Ameliorated ET-1-Mediated Vasoconstriction in Rats with PAH. To investigate the effect of rosiglitazone on vasoconstriction of pulmonary arteries induced by ET1, pulmonary arteries from normoxia-, chronic hypoxia$(\mathrm{CH}-)$, and rosiglitazone-treated $\mathrm{CH}$-rats were dissected from groups of animals for isometric tension measurement responding to ET-1. The ET-1-induced contractions in pulmonary arteries were elevated in PAH rats compared to the normoxic rats. Treatment with PPAR $\gamma$ agonist rosiglitazone (20 $\mathrm{mg} / \mathrm{kg}$ per day) reversed the vasocontractive effect of ET-1 (Figure 1). However, this effect of rosiglitazone was abolished by the treatment with the inhibitor of endothelial nitric

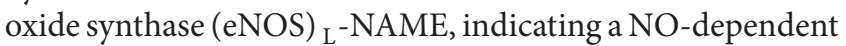
mechanism (Figure 2).
3.2. Rosiglitazone Increased $E T_{B} R$ Protein Levels in Pulmonary Arteries from PAH Rats. To understand the mechanism for the effect of rosiglitazone on ET-1-induced vasocontraction in pulmonary arteries, we examined the protein level of $\mathrm{ET}_{\mathrm{B}} \mathrm{R}$ with Western blotting. As shown in Figure 3, $\mathrm{ET}_{\mathrm{B}} \mathrm{R}$ protein level was unaltered in the pulmonary arteries from $\mathrm{CH}$-induced $\mathrm{PAH}$ rats. However, rosiglitazone treatment increased the expression of $\mathrm{ET}_{\mathrm{B}} \mathrm{R}$. In contrast, it reduced the expression of $\mathrm{ET}_{\mathrm{A}} \mathrm{R}$ (Supplemental Figure 2 available online at http://dx.doi.org/10.1155/2014/374075).

3.3. Inhibitory Effect of Rosiglitazone Is Abolished by $E T_{B} R A n$ tagonist. To examine the functional role of $\mathrm{ET}_{\mathrm{B}} \mathrm{R}$ in mediating the rosiglitazone effect on ET-1-induced vasoconstriction, pulmonary arteries were dissected from normoxia-, $\mathrm{CH}-$, and rosiglitazone-treated $\mathrm{CH}$-rats to measure the ET-1-responsive isometric tension in the presence or absence of A192621, a selective $\mathrm{ET}_{\mathrm{B}} \mathrm{R}$ antagonist. In normoxic and $\mathrm{PAH}$ rats, A192621 (10 nmol/L) did not significantly alter the ET-1induced contraction (Figures 4(a) and 4(b)). However, in the rosiglitazone-treated pulmonary arteries, A192621 abolished the ameliorative effect on the ET-1-induced vasocontraction (Figure 4(c)).

\section{Discussion}

The vascular effects of ET-1 are mediated by 2 pharmacologically distinct $\mathrm{G}$ protein-coupled receptors, $\mathrm{ET}_{\mathrm{A}} \mathrm{R}$ and $\mathrm{ET}_{\mathrm{B}} \mathrm{R}$ [29]. $\mathrm{ET}_{\mathrm{A}} \mathrm{R}$ is mostly expressed in SMCs and mediates the vasoconstrictive and proliferative effects of ET-1 [30]. However, $\mathrm{ET}_{\mathrm{B}} \mathrm{R}$ expressed in ECs mediates endothelialdependent vasodilatation by stimulating the production of $\mathrm{NO}$ and prostacyclin, prevents apoptosis, and promotes the 


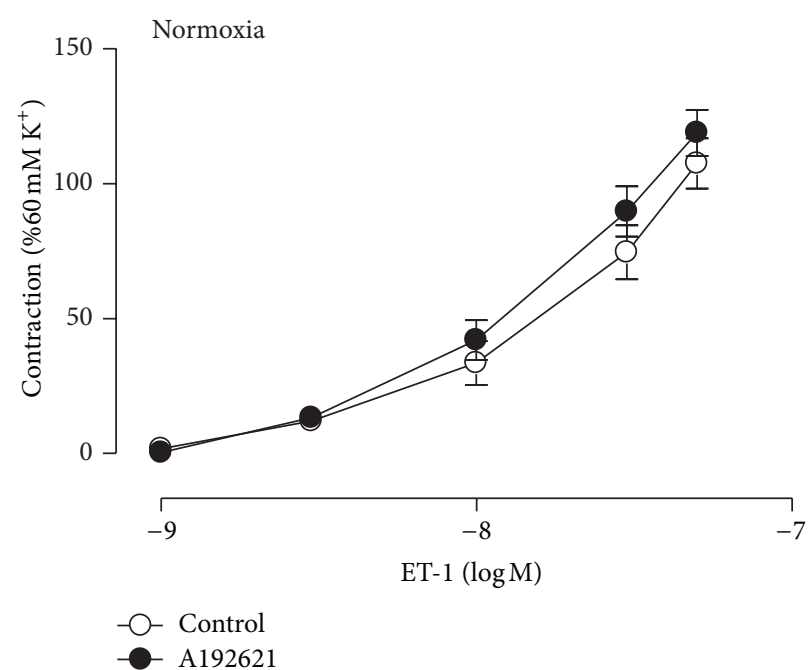

(a)

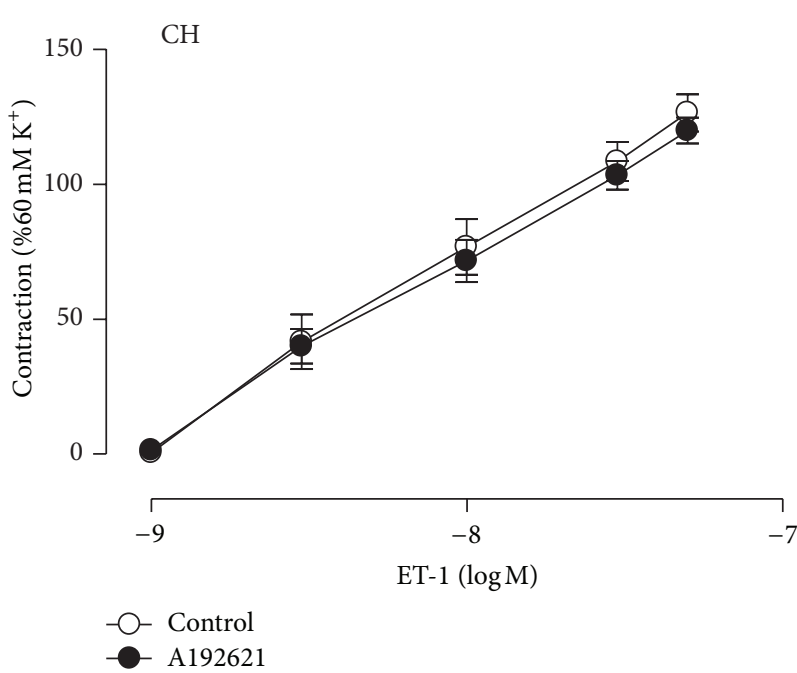

(b)

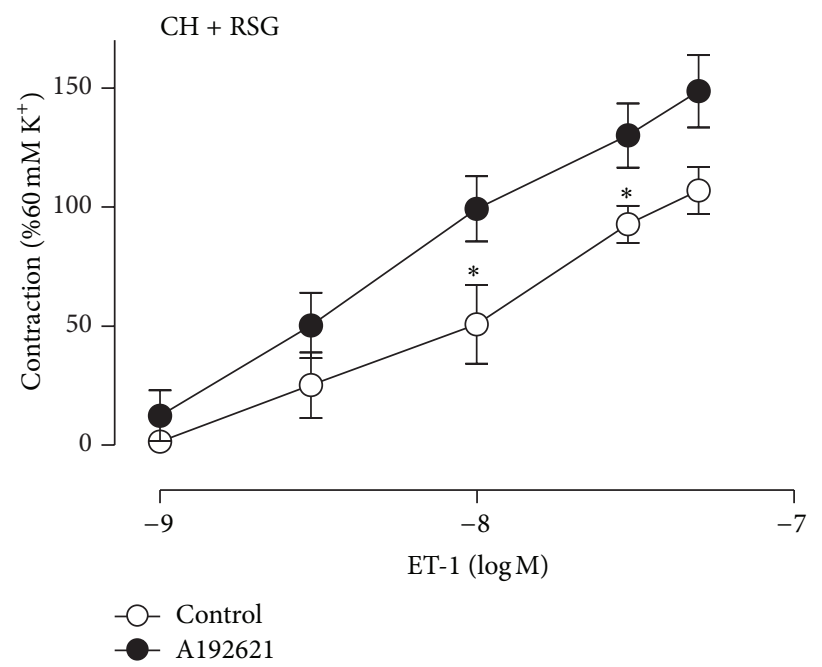

(c)

FIGURE 4: The ameliorative effect of RSG on ET-1-induced contractions was abrogated by $\mathrm{ET}_{\mathrm{B}} \mathrm{R}$ antagonist. Concentration-dependent contractions to ET-1 pretreated with $\mathrm{ET}_{\mathrm{B}} \mathrm{R}$ antagonist A192621 (10 nmol/L) in pulmonary arteries from normoxia- (a), CH (b), or RSG-treated $\mathrm{CH}$ (c) rats. Data were mean \pm SEM from 5 to 8 rats. ${ }^{*} P<0.05$ versus control.

clearance of ET-1 [31, 32]. $\mathrm{ET}_{\mathrm{B}} \mathrm{R}$ is present in low densities on vascular smooth muscle cells where its activation induces vasoconstriction $[33,34]$. Since $\mathrm{ET}_{\mathrm{B}} \mathrm{R}$ elicits vasodilation and vasoconstriction, its vascular functions in pulmonary arterial hypertension need to be further characterized. $\mathrm{ET}_{\mathrm{B}} \mathrm{R}$ deficient rats developed exacerbated $\mathrm{PAH}$ after exposure to chronic hypoxia, characterized by elevated pulmonary arterial pressure, diminished cardiac output, increased right ventricular hypertrophy, and increased total pulmonary resistance. Plasma ET-1 level and mRNA of ET-converting enzyme-1 (ECE-1) were much higher in lungs from $\mathrm{ET}_{\mathrm{B}} \mathrm{R}$ deficient rats compared with control rats. $\mathrm{In}_{\mathrm{ET}} \mathrm{R}$-deficient rats, the pulmonary vessels showed less endothelial NO synthase (eNOS) and NO production, supporting a role of $\mathrm{NO}$ in $\mathrm{ET}_{\mathrm{B}} \mathrm{R}$-mediated vasodilation in the pulmonary vasculature [35]. Other studies in monocrotaline (MCT) induced
PAH rats also showed that $\mathrm{ET}_{\mathrm{B}} \mathrm{R}$ deficiency accelerated the progression of $\mathrm{PAH}$ and neointimal lesion [36, 37]. Although both $\mathrm{ET}_{\mathrm{A}} \mathrm{R}$ antagonist (ambrisentan) and dual $\mathrm{ET}_{\mathrm{A}} \mathrm{R} / \mathrm{ET}_{\mathrm{B}} \mathrm{R}$ antagonist (bosentan) have been approved for treatment of $\mathrm{PAH}$ [38], selective antagonists for $\mathrm{ET}_{\mathrm{A}} \mathrm{R}$ and $\mathrm{ET}_{\mathrm{B}} \mathrm{R}$ appeared to have different effects on PAH. In a dog model for PAH, $\mathrm{ET}_{\mathrm{B}} \mathrm{R}$ antagonist RES-701-1 was found to increase pulmonary arterial pressure whereas sarafotoxin $S 6 c$, an $\mathrm{ET}_{B} \mathrm{R}$ agonist, decreased pulmonary arterial resistance [39]. In addition, $\mathrm{ET}_{\mathrm{B}} \mathrm{R}$ antagonist also elevated ET-1 concentrations in both in vivo and in vitro studies [40]. These findings suggest that activation of $\mathrm{ET}_{\mathrm{B}} \mathrm{R}$ may play a protective role in the PAH.

In addition to three categories of FDA-approved treatments including prostanoids, ET-1 receptor antagonists, and phosphodiesterase 5 (PDE5) inhibitors, PPAR $\gamma$ agonists thiazolidinediones (TZDs) including rosiglitazone and 
pioglitazone have shown beneficial effects in animal models of PAH. In rodent PAH models induced by MCT or hypoxia and those associated with insulin resistance, TZDs were found to effectively reduce pulmonary arterial pressure and right ventricular hypertrophy [21, 22, 24, 25, 41]. Recently, we showed that rosiglitazone reversed pulmonary arterial remodeling and inhibited vasoconstriction in response to serotonin in the rat PAH models induced by MCT and hypoxia. Although the molecular mechanisms underlying the TZD effects on PAH development remain unclear, a generally accepted hypothesis is that TZDs may act via their receptor $\operatorname{PPAR} \gamma$ to modulate the expression of key genes involved in the pathogenesis of PAH such as ET-1, eNOS, p2 $7^{\mathrm{KIP} 1}$, adiponectin, apoE, MMP, and RhoA/ROCK. In this study, we provided in vivo evidence that rosiglitazone ameliorated ET-1-induced vasocontraction in the pulmonary arteries of PAH rats (Figure 1). The ameliorative effect of rosiglitazone was mediated via differential regulation of ET-1 receptors. In particular, the upregulation of $\mathrm{ET}_{\mathrm{B}} \mathrm{R}$ might play a major role because rosiglitazone treatment increased the expression of $\mathrm{ET}_{\mathrm{B}} \mathrm{R}$ in the pulmonary arteries (Figure 3 ) and A192621, a selective antagonist of $\mathrm{ET}_{B} \mathrm{R}$, abrogated the effect (Figure 4). Conversely, rosiglitazone inhibited the induction of $\mathrm{ET}_{\mathrm{A}} \mathrm{R}$ in the pulmonary arteries of PAH rats (Supplemental Figure 2). It is conceivable that rosiglitazone may have the vasoprotective effects by altering the ratio of $\mathrm{ET}_{\mathrm{A} / \mathrm{B}}$ receptors. $\mathrm{ET}_{\mathrm{B}} \mathrm{R}$ in ECs may increase $\mathrm{Ca}^{2+}$ influx and the activation of eNOS, which leads to the production of NO and induction of vascular relaxation. This notion is corroborated with the result that the effect of rosiglitazone was abolished in the presence of ${ }_{L}-\mathrm{NAME}$, an inhibitor of eNOS (Figure 2). Importantly, the induction of endothelial $\mathrm{ET}_{\mathrm{B}} \mathrm{R}$ is considered to be a PPAR $\gamma$-specific mechanism as we previously identified $\mathrm{ET}_{\mathrm{B}} \mathrm{R}$ to be a direct target gene of PPAR $\gamma$ [28].

\section{Conclusions}

In conclusion, we demonstrated that rosiglitazone upregulated the expression of $\mathrm{ET}_{\mathrm{B}} \mathrm{R}$, which mediated the decreased vasoconstriction in the rat models of PAH. This finding suggested a new mechanism for the protective role of PPAR $\gamma$ in the development of PAH.

\section{Conflict of Interests}

The authors declare that there is no conflict of interests regarding the publication of this paper.

\section{Acknowledgments}

This work was supported by Grants from the National Science Foundation of China (81220108005, 81300189, 81241146, and 81121061), the China Postdoctoral Science Foundation, the Postdoctoral Fellowship of Peking-Tsinghua Center for Life Sciences, and the Ministry of Science and Technology (2010CB912500 and 2012CB518000).

\section{References}

[1] H. W. Farber and J. Loscalzo, "Mechanisms of disease: pulmonary arterial hypertension," New England Journal of Medicine, vol. 351, no. 16, pp. 1655-1665, 2004.

[2] T. Miyauchi, R. Yorikane, S. Sakai et al., "Contribution of endogenous endothelin-1 to the progression of cardiopulmonary alterations in rats with monocrotaline-induced pulmonary hypertension," Circulation Research, vol. 73, no. 5, pp. 887-897, 1993.

[3] D. J. Stewart, R. D. Levy, P. Cernacek, and D. Langleben, "Increased plasma endothelin-1 in pulmonary hypertension: marker or mediator of disease?" Annals of Internal Medicine, vol. 114, no. 6, pp. 464-469, 1991.

[4] A. Giaid, M. Yanagisawa, D. Langleben et al., "Expression of endothelin-1 in the lungs of patients with pulmonary hypertension," New England Journal of Medicine, vol. 328, no. 24, pp. 1732-1739, 1993.

[5] T. J. Stelzner, R. F. O’Brien, M. Yanagisawa et al., "Increased lung endothelin-1 production in rats with idiopathic pulmonary hypertension," American Journal of Physiology, vol. 262, no. 5, pp. L614-L620, 1992.

[6] S. T. Bonvallet, M. R. Zamora, K. Hasunuma et al., "BQ123, an ETA-receptor antagonist, attenuates hypoxic pulmonary hypertension in rats," American Journal of Physiology, vol. 266, no. 4, pp. H1327-H1331, 1994.

[7] V. S. DiCarlo, S.-J. Chen, Q. C. M. Qing Cheng Meng et al., "ETA-receptor antagonist prevents and reverses chronic hypoxia-induced pulmonary hypertension in rat," American Journal of Physiology, vol. 269, no. 5, pp. L690-L697, 1995.

[8] D. D. Ivy, T. A. Parker, J. W. Ziegler et al., "Prolonged endothelin A receptor blockade attenuates chronic pulmonary hypertension in the ovine fetus," Journal of Clinical Investigation, vol. 99, no. 6, pp. 1179-1186, 1997.

[9] N. Davie, S. J. Haleen, P. D. Upton et al., "ETA and ETB receptors modulate the proliferation of human pulmonary artery smooth muscle cells," American Journal of Respiratory and Critical Care Medicine, vol. 165, no. 3, pp. 398-405, 2002.

[10] S. Soma, H. Takahashi, M. Muramatsu, M. Oka, and Y. Fukuchi, "Localization and distribution of endothelin receptor subtypes in pulmonary vasculature of normal and hypoxia-exposed rats," American Journal of Respiratory Cell and Molecular Biology, vol. 20, no. 4, pp. 620-630, 1999.

[11] B. Rondelet, F. Kerbaul, S. Motte et al., "Bosentan for the prevention of overcirculation-induced experimental pulmonary arterial hypertension," Circulation, vol. 107, no. 9, pp. 1329-1335, 2003.

[12] J. Lutz, M. Gorenflo, M. Habighorst, M. Vogel, P. E. Lange, and B. Hocher, "Endothelin-1- and endothelin-receptors in lung biopsies of patients with pulmonary hypertension due to congenital heart disease," Clinical Chemistry and Laboratory Medicine, vol. 37, no. 4, pp. 423-428, 1999.

[13] J. Wong, V. M. Reddy, K. Hendricks-Munoz, J. R. Liddicoat, R. Gerrets, and J. R. Fineman, "Endothelin-1 vasoactive responses in lambs with pulmonary hypertension and increased pulmonary blood flow," American Journal of Physiology, vol. 269, no. 6, pp. H1965-H1972, 1995.

[14] D. D. Ivy, J. W. Ziegler, M. F. Dubus, J. J. Fox, J. P. Kinsella, and S. H. Abman, "Chronic intrauterine pulmonary hypertension alters endothelin receptor activity in the ovine fetal lung," Pediatric Research, vol. 39, no. 3, pp. 435-442, 1996. 
[15] D. D. Ivy, T. D. Le Cras, M. P. Horan, and S. H. Abman, "Chronic intrauterine pulmonary hypertension increases preproendothelin- 1 and decreases endothelin B receptor mRNA expression in the ovine fetal lung," Chest, vol. 114, no. 1, supplement, p. 65, 1998.

[16] G. Hansmann and R. T. Zamanian, "PPARgamma activation: a potential treatment for pulmonary hypertension," Science Translational Medicine, vol. 1, no. 12, pp. 12-14, 2009.

[17] N. Wang, L. Verna, N.-G. Chen et al., "Constitutive activation of peroxisome proliferator-activated receptor- $\gamma$ suppresses proinflammatory adhesion molecules in human vascular endothelial cells," Journal of Biological Chemistry, vol. 277, no. 37, pp. 34176-34181, 2002.

[18] J. Li and N. Wang, "Peroxisome proliferator-activated receptor$\gamma$ in vascular biology," Cardiovascular and Hematological Disorders, vol. 7, no. 2, pp. 109-117, 2007.

[19] M. Hamblin, L. Chang, Y. Fan, J. Zhang, and Y. E. Chen, "PPaRs and the cardiovascular system," Antioxidants and Redox Signaling, vol. 11, no. 6, pp. 1415-1452, 2009.

[20] S. Ameshima, H. Golpon, C. D. Cool et al., "Peroxisome proliferator-activated receptor gamma (PPAR $\gamma)$ expression is decreased in pulmonary hypertension and affects endothelial cell growth," Circulation Research, vol. 92, no. 10, pp. 1162-1169, 2003.

[21] E. K. Kim, J.-H. Lee, Y.-M. Oh, Y.-S. Lee, and S.-D. Lee, "Rosiglitazone attenuates hypoxia-induced pulmonary arterial hypertension in rats," Respirology, vol. 15, no. 4, pp. 659-668, 2010.

[22] R. E. Nisbet, J. M. Bland, D. J. Kleinhenz et al., "Rosiglitazone attenuates chronic hypoxia-induced pulmonary hypertension in a mouse model," American Journal of Respiratory Cell and Molecular Biology, vol. 42, no. 4, pp. 482-490, 2010.

[23] G. Hansmann, V. A. de Jesus Perez, T.-P. Alastalo et al., "An antiproliferative BMP-2/PPAR $\gamma /$ apoE axis in human and murine SMCs and its role in pulmonary hypertension," Journal of Clinical Investigation, vol. 118, no. 5, pp. 1846-1857, 2008.

[24] J. T. Crossno Jr., C. V. Garat, J. E. B. Reusch et al., "Rosiglitazone attenuates hypoxia-induced pulmonary arterial remodeling," American Journal of Physiology, vol. 292, no. 4, pp. L885-L897, 2007.

[25] G. Hansmann, R. A. Wagner, S. Schellong et al., "Pulmonary arterial hypertension is linked to insulin resistance and reversed by peroxisome proliferator-activated receptor- $\gamma$ activation," Circulation, vol. 115, no. 10, pp. 1275-1284, 2007.

[26] P. Delerive, F. Martin-Nizard, G. Chinetti et al., "Peroxisome proliferator-activated receptor activators inhibit thrombininduced endothelin-1 production in human vascular endothelial cells by inhibiting the activator protein-1 signaling pathway," Circulation Research, vol. 85, no. 5, pp. 394-402, 1999.

[27] F. Martin-Nizard, C. Furman, P. Delerive et al., "Peroxisome proliferator-activated receptor activators inhibit oxidized lowdensity lipoprotein-induced endothelin-1 secretion in endothelial cells," Journal of Cardiovascular Pharmacology, vol. 40, no. 6, pp. 822-831, 2002.

[28] J. Tian, W. T. Wong, X. Y. Tian, P. Zhang, Y. Huang, and N. Wang, "Rosiglitazone attenuates endothelin-1-induced vasoconstriction by upregulating endothelial expression of endothelin b receptor," Hypertension, vol. 56, no. 1, pp. 129-135, 2010.

[29] A. P. Davenport, "International Union of Pharmacology-29. Update on endothelin receptor nomenclature," Pharmacological Reviews, vol. 54, no. 2, pp. 219-226, 2002.
[30] K. Hosoda, K. Nakao, H.-A. Hiroshi-Arai et al., "Cloning and expression of human endothelin-1 receptor cDNA," FEBS Letters, vol. 287, no. 1-2, pp. 23-26, 1991.

[31] Y. Hirata, T. Emori, S. Eguchi et al., "Endothelin receptor subtype B mediates synthesis of nitric oxide by cultured bovine endothelial cells," Journal of Clinical Investigation, vol. 91, no. 4, pp. 1367-1373, 1993.

[32] J. Dupuis, C. A. Goresky, and A. Fournier, "Pulmonary clearance of circulating endothelin-1 in dogs in vivo: exclusive role of ETB receptors," Journal of Applied Physiology, vol. 81, no. 4, pp. 1510-1515, 1996.

[33] M. M. Hynynen and R. A. Khalil, "The vascular endothelin system in hypertension-recent patents and discoveries," Recent Patents on Cardiovascular Drug Discovery, vol. 1, no. 1, pp. 95108, 2006.

[34] M. Clozel, G. A. Gray, V. Breu, B.-M. Loffler, and R. Osterwalder, "The endothelin ETB receptor mediates both vasodilation and vasoconstriction in vivo," Biochemical and Biophysical Research Communications, vol. 186, no. 2, pp. 867-873, 1992.

[35] D. Dunbar Ivy, M. Yanagisawa, C. E. Gariepy, S. A. Gebb, K. L. Colvin, and I. F. McMurtry, "Exaggerated hypoxic pulmonary hypertension in endothelin B receptor-deficient rats," American Journal of Physiology, vol. 282, no. 4, pp. L703-L712, 2002.

[36] D. D. Ivy, I. F. McMurtry, K. Colvin et al., "Development of occlusive neointimal lesions in distal pulmonary arteries of endothelin B receptor-deficient rats: a new model of severe pulmonary arterial hypertension," Circulation, vol. 111, no. 22, pp. 2988-2996, 2005.

[37] M. Nishida, Y. Okada, K. Akiyoshi et al., "Role of endothelin ETB receptor in the pathogenesis of monocrotaline-induced pulmonary hypertension in rats," European Journal of Pharmacology, vol. 496, no. 1, pp. 159-165, 2004.

[38] C. F. Opitz, R. Ewert, W. Kirch, and D. Pittrow, "Inhibition of endothelin receptors in the treatment of pulmonary arterial hypertension: does selectivity matter?" European Heart Journal, vol. 29, no. 16, pp. 1936-1948, 2008.

[39] M. Okada, C. Yamashita, M. Okada, and K. Okada, "Role of endothelin-1 in beagles with dehydromonocrotaline-induced pulmonary hypertension," Circulation, vol. 92, no. 1, pp. 114-119, 1995.

[40] T. Attinà, R. Camidge, D. E. Newby, and D. J. Webb, "Endothelin antagonism in pulmonary hypertension, heart failure, and beyond," Heart, vol. 91, no. 6, pp. 825-831, 2005.

[41] Y. Liu, X.Y. Tian, G. Mao et al., "Peroxisome proliferator-activated receptor-gamma ameliorates pulmonary arterial hypertension by inhibiting 5-hydroxytryptamine $2 \mathrm{~B}$ receptor," Hypertension, vol. 60, no. 6, pp. 1471-1478, 2012. 


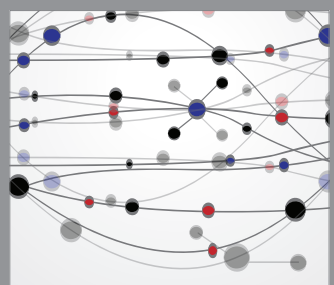

The Scientific World Journal
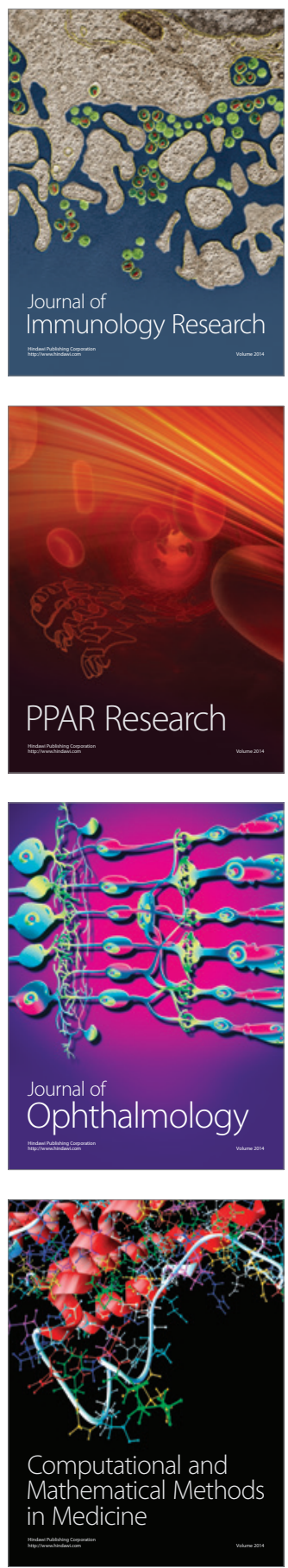

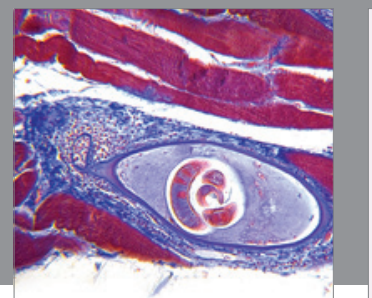

Gastroenterology

Research and Practice
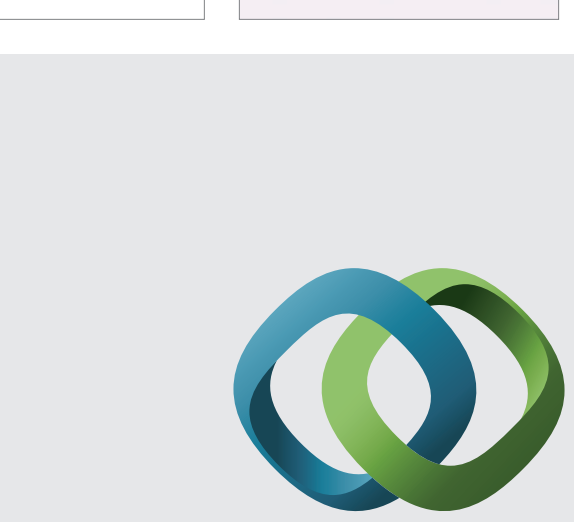

\section{Hindawi}

Submit your manuscripts at

http://www.hindawi.com
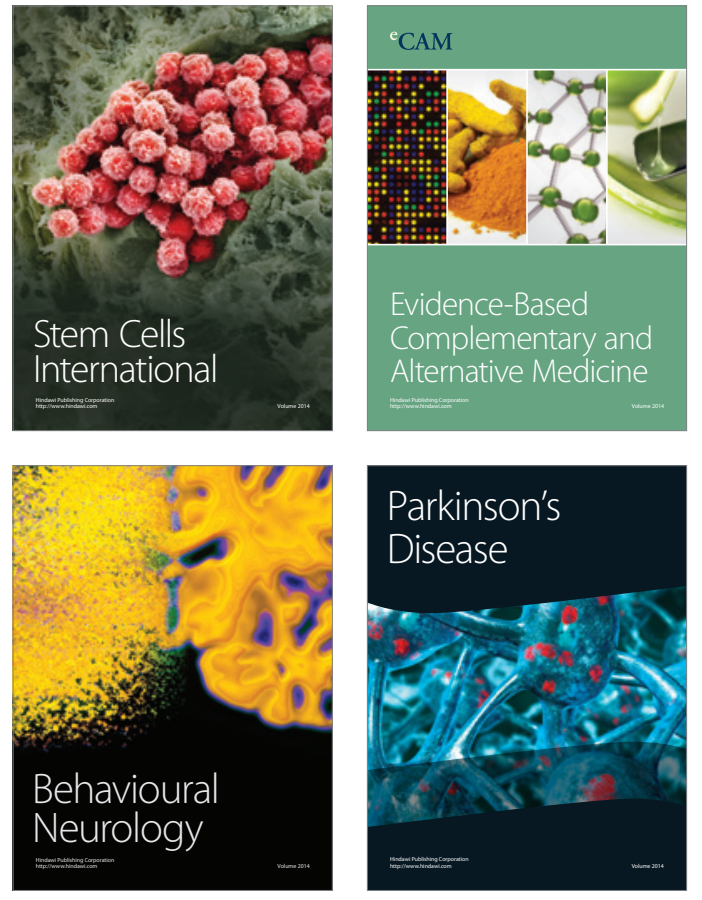
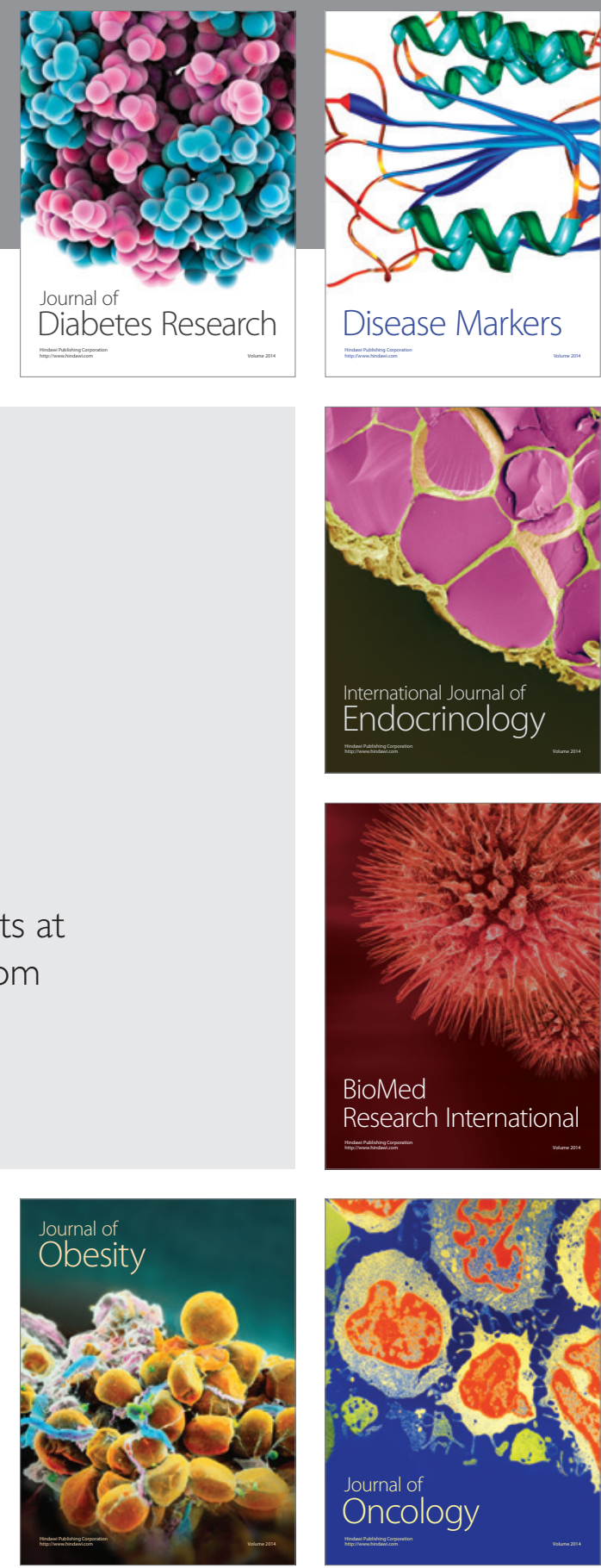

Disease Markers
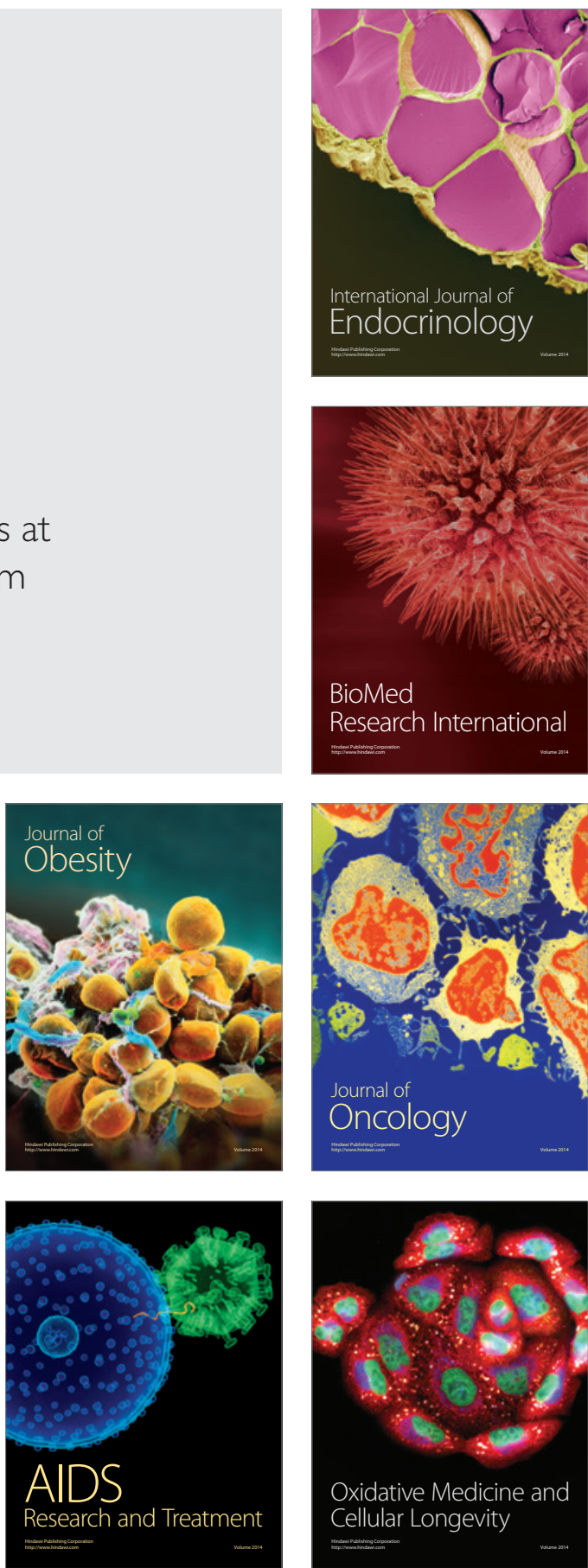